\title{
Bone morphogenetic protein 2: heterologous expression and potential in bone regeneration
}

\author{
Proteína morfogenética de hueso 2: expresión heteróloga y potencial en la regeneración ósea
}

\author{
Andrea Mesa-Restrepo ${ }^{1}$, Juan Fernando Alzate ${ }^{2}$, Edwin Bairon Patiño-Gonzalez ${ }^{3 *}$
}

\begin{abstract}
Currently, bone morphogenetic protein 2 (BMP-2) is one of the two osteoinductive growth factors used in medical devices to promote bone formation. Typically, this protein is bought from commercial houses at high rates and in small quantities that are not enough to cover clinical needs. Because of this, it has been proposed that research centers use their own heterologous expression systems to have a constant supply of BMP-2. The aim of this study was to standardize the heterologous expression of BMP-2 and evaluate its osteoinductive activity in vitro. Our procedure for expression and purification was based on recombinant DNA technology using the plasmid pET-28 and IPTG as inductor. After extracting the protein from inclusion bodies, folding it and modifying it via a redox system, we observed via electrophoresis a $26 \mathrm{kDa}$ dimer. We evaluated its osteoinductive activity in myoblastic $\mathrm{C} 2 \mathrm{C} 12$ by quantifying enzymatically the activity of alkaline phosphate (ALP) and staining mineralization nodules. ALP activity is proportional to BMP-2 concentration, increasing $90 \%$ at $3 \mu \mathrm{g} / \mathrm{mL}$. These cells form calcium nodules, mineralizing $50 \%$ of the area.
\end{abstract}

Keywords: Alkaline phosphatase, Cells C2C12, Refolding protein, rhBMP-2

\section{Resumen}

Actualmente la proteína morfogénica ósea 2 (BMP-2) es uno de los dos factores de crecimiento más osteoinductivos usado clínicamente en dispositivos médicos que promueve la formación de hueso. Normalmente esta proteína es comprada a altos precios y en cantidades pequeñas que no alcanzan a cubrir las necesidades clínicas. Debido a esto, se ha propuesto que centros de investigación utilicen sus propios sistemas heterólogos para obtener un suministro constante. El objetivo de este trabajo es estandarizar la expresión heteróloga de la BMP-2 y evaluar su actividad osteoinductiva in vitro. Nuestro procedimiento para la expresión y purificación se basó en la tecnología de DNA recombinante usando el plásmido pET-28 e IPTG como inductor. Después de extraer la proteína de los cuerpos de inclusión, renaturalizarla y modificarla usando un sistema redox, se observó mediante electroforesis un dímero de $26 \mathrm{kDa}$. Se evaluó su actividad osteoinductiva en células mioblásticas C2C12 cuantificando enzimáticamente la actividad de la fosfatasa alcalina (ALP) y realizando una tinción de los nódulos de mineralización. La actividad de la fosfatasa alcalina fue proporcional a la concentración de BMP-2, obteniendo un aumento del $90 \%$ a concentraciones de $3 \mu \mathrm{g} / \mathrm{mL}$. Estas células formaron nódulos de calcio, mineralizando un $50 \%$ la superficie.

Palabras claves: Células C2C12, Fosfatasa alcalina, Renaturalización, rhBMP-2

\footnotetext{
1. Grupo de Biomateriales Avanzados y Medicina Regenerativa, Universidad de Antioquia, Medellín, Colombia.

2. Centro Nacional de Secuenciación Genómica, Universidad de Antioquia, Medellín, Colombia.

3. Grupo Bioquímica Estructural de Macromoléculas, Universidad de Antioquia, Medellín, Colombia.

* Corresponding author: <edwin.patino@udea.edu.co>
} 


\section{INTRODUCTION}

Bone is a hard tissue as a result of a mineralization process. The inorganic phosphate necessary for bone mineralization is obtained from different substrates, such as pyridoxal phosphate, inorganic pyrophosphate or phosphoethanolamine (Saraff et al., 2016). These substrates are hydrolyzed by alkaline phosphatases (ALP) to provide inorganic phosphate for bone tissue development. There is a direct relationship between low ALP activity and bone disorders, which further demonstrates the importance of ALP in the mineralization process (Uday et al., 2019). The production of ALP in different cell lines has been used since 1994 to prove the biological activity of Bone Morphogenetic Protein (BMP) ligands, which are members of the transforming growth factor superfamily (Allendorph et al., 2006; Krishnakumar et al., 2017; Rahman et al., 2015). Of all BMP ligands, BMP-2 and BMP-7 have been shown as the main factors to induce complete bone formation (Kim et al., 2019; Yilgor et al., 2009). Additionally, BMP2 is a critical factor in the fracture healing process, as demonstrated by the inability of BMP-2 deficient mice to initiate this process (Bahney et al., 2019). The above evidence established BMP-2 as a pivotal mediator necessary for bone formation.

At the tissue level, BMP-2 becomes biologically active after the dimerization of two monomers of 114 residues each, giving the protein a relative molecular mass of $26 \mathrm{kDa}$. The dimerization of two monomers is maintained by three intrachain disulfide bridges (Scheufler et al., 1999). The signaling pathways are initiated when BMP-2 binds its receptor, which has a serine/threonine kinase activity. The transphosphorylation occurs after the BMP-2 binds to receptor type II and this receptor proceeds to phosphorylate to receptor type I. The downstream effects after phosphorylation of receptor type II and type I are the phosphorylation of Smad transcription factors (Miyazono et al., 2010). Smads are translocated into the nucleus and bind to regulatory regions of BMP responsive genes, among them RUNX2/CBF (Bahney et al., 2019; Mevel et al., 2019).

As mentioned above, BMP-2 plays an important role in bone formation. Its potent osteogenic abilities have been used to improve fracture repair in the USA (Ruehle et al., 2019). Commercially, a BMP-2 based collagen sponge (Infuse) (Durham et al., 2018) has been developed by Medtronic; however, this device causes swelling in the neck and life-threatening complications. Thus, it is necessary to develop safer and cost-effective devices.

With the development of recombinant technology, mass production of BMP-2 becomes easier. Although multiple commercial houses sell this product (Thermo Fisher Scientific, R\&D systems and SigmaAldrich), they sell small amounts at a high cost (317 USD per $10 \mu \mathrm{g}$ protein). This is insufficient for clinical usage (up to $1.5 \mathrm{mg} / \mathrm{mL}$ ). Additionally, recombinant BMP-2, like many proteins expressed in bacteria, forms aggregates in structures known as inclusion bodies (IB) (Long et al., 2006). In IB, proteins are unfolded, rendering them inactive. Therefore, an in vitro refolding step is needed to solubilize and activate the accumulated proteins (Krauss et al., 2013). The refolding process is the main bottleneck in protein production. This process is time consuming, which increases the cost of production and limits its scalability in an industrial setting (Vallejo et al., 2002).

This work aims to establish a protocol to obtain recombinant human BMP-2 (rhBMP-2) in a costefficient way. In this paper, we describe the production of rhBMP-2 in Escherichia coli (E. coli) engineered in a synthetic gene. Our results showed a feasible BMP-2 production system that can synthesize rhBMP-2 in a cost-efficient manner, which has potential applications in bone tissue engineering.

\section{MATERIALS AND METHODS}

\section{Reagents}

Human recombinant BMP-2 protein was purchased from Gibco. The human cell lines $\mathrm{C} 2 \mathrm{C} 12$ and Saos-2 were obtained from ATCC. The basic chemicals were obtained from Sigma-Aldrich, Fermentas and Amresco. The enzymes were purchased from New England Biolab and Fermentas. The protein was dialyzed in Spectra/por 3 regenerated cellulose membranes from Millipore. The Spectra/por 3 (Thermo Fisher 
Scientific) has a Molecular Weight Cutoff (MWCO) of $3500 \mathrm{kDa}$, a diameter of $11.5 \mathrm{~mm}$, and a capacity of volume/length of $1 \mathrm{~mL} / \mathrm{cm}$. Proteins were concentrated by ultra-filtration (Amicon system) with YM3 membranes (3000 MWCO) (Merck Millipore). For bacteria and mammalian culture medium, Milli Q water (resistivity of $18.2 \mathrm{M} \Omega \mathrm{cm}$ at $25^{\circ} \mathrm{C}$ ) was used.

\section{Synthetic oligonucleotides}

The synthetic oligos were purchased from Macrogen. The oligos cover the CDS reported for amino acids 283-396 of the mature part of human BMP-2 (hBMP$2)$.

PCR_BMP2_fw:CCATGGCGCAGGCGAAACAT AAAC

PCR_BMP2_rv:GGATCCTTATTAGCGGCAGC

B5_OLIGOFW:CCATGGCGCAGGCGAAACAT AAACAGCGCAAACGCCTGAAAAGCAGCTG CAAACGCCATCCGCTGTATGTGGATTTTAG CGATGTGGGCTGGAACGATTGGATTGTG

B5_OLIGORV:GCATGGTTGGTGCTGTTCAG ATGATCCGCCAGCGGAAACGGGCATTCGC CGTGGCAATAAAACGCATGATAGCCCGGC GGCGCCACAATCCAATCGTTCCAGCCC

B3_OLIGOFW:TCTGAACAGCACCAACCATG CGATTGTGCAGACCCTGGTGAACAGCGTG AACAGCAAAATTCCGAAAGCGTGCTGCGT GCCGACCGAACTGAGCGCGATTAGCATGC

\section{B3_OLIGORV:GGATCCTTATTAGCGGCAGCC GCAGCCTTCCACCACCATATCCTGATAGTT TTTCAGCACCACTTTTTCGTTTTCATCCAG ATACAGCATGCTAATCGCGCTCAGT \\ hBMP-2 synthetic gene construction and DNA se- quencing}

To produce the synthetic gene that codes for hBMP-2 CDS, we followed a strategy of long primer synthesis and joined the fragments using DNA polymerase and PCR. The CDS was divided into two blocks, a 5' end and a 3' end. These blocks retained an overlapping region of 22 bases to facilitate the fusion of the blocks via PCR in a final step. Each block was generated by the annealing and elongation of two long primers that have a complementary region at the end of both oligonucleotides. The conditions for this reaction were: long primers $0.8 \mu \mathrm{M}$; Taq DNA polymerase 2.5 $\mathrm{U} / 100 \mu \mathrm{L}$; Taq Buffer 1X (Thermo Fisher); dNTPs at $0.05 \mathrm{mM}$ (Thermo Fisher). Incubation conditions in a Biorad C1000 cycler $^{\mathrm{TM}}$ were: $95^{\circ} \mathrm{C} 1 \mathrm{~min}, 55^{\circ} \mathrm{C}$ $20 \mathrm{sec}, 72^{\circ} \mathrm{C} 2 \mathrm{~min}$. After the annealing step, DNA polymerase (Taq) could elongate the long primers upon the primed overlapping region and produced a dsDNA molecule of both blocks independently, a 5' end and a 3' end. At the final step, a PCR was performed as follows: $1 \mu \mathrm{L}$ of the produced dsDNA of each block was added to the reaction as well as a PCR forward primer (PCR_BMP2_fw, $2 \mu \mathrm{M}$ ) directed to the 5' end of the 5' block and a reverse primer (PCR_BMP2_rv, $2 \mu \mathrm{M}$ ) directed to the 3' end of the 3 ' block. The PCR conditions were: $50 \mu \mathrm{L}$ final volume; Taq DNA polymerase $2.5 \mathrm{U} / 100 \mu \mathrm{L} ; \mathrm{MgCl}_{2} 1.5$ $\mathrm{mM}$; dNTPs at $0.2 \mathrm{mM}$; program: $95^{\circ} \mathrm{C} 1 \mathrm{~min},\left(95^{\circ} \mathrm{C}\right.$ $\left.30 \mathrm{sec}, 55^{\circ} \mathrm{C} 15 \mathrm{sec}, 72^{\circ} \mathrm{C} 30 \mathrm{sec}\right) \times 25$ cycles, $72^{\circ} \mathrm{C}$ $20 \mathrm{~min}$. This final reaction produced a full-length synthetic CDS of hBMP-2 gene that was amplified due to the overlapping 22 bases region present within the 5' and 3' blocks. Furthermore, these last PCR primers also have the DNA target for the restriction enzymes NcoI and BamHI for the 5' and 3' ends, respectively. The last PCR products were ligated into pTZ vector according to the manufacturer's protocol (Thermo Fisher Scientific). The ligation reaction was carried out with $3 \mu \mathrm{L}$ PCR products that were mixed with $1 \mu \mathrm{L}$ pTZ plasmid plus $1 \mu \mathrm{L}$ ligation buffer $\mathrm{T} 4$ DNA ligase and $1 \mu \mathrm{L}$ T4 DNA ligase. The ligation reaction was incubated for $2 \mathrm{hr}$ at room temperature. Afterwards, the ligation product was transformed into $100 \mu \mathrm{L}$ of XL1 blue E. coli cells. Transformed cells were spread out on LB agar plates supplemented with $50 \mu \mathrm{g} / \mathrm{mL}$ of kanamycin (Merck). The next day, ten colonies were cultured in $3 \mathrm{~mL}$ Luria Bertani broth supplemented with $50 \mu \mathrm{g} / \mathrm{mL}$ of kanamycin.

Plasmids from ten colonies were purified using the miniprep kit (Quiagen Spin miniprep kit Cat. No. 27104). Five microliters of each plasmid were mixed with $20 \mu \mathrm{L}$ PCR master mix $(2.5 \mu \mathrm{L} 10 \mathrm{X}$ Taq buffer, $2 \mu \mathrm{L}$ of $25 \mathrm{mM} \mathrm{MgCl}_{2}, 2 \mu \mathrm{L}$ of $2 \mathrm{mM}$ dNTPs, $1 \mu \mathrm{L}$ of 2 mM PCR_BMP2_fw, $1 \mu \mathrm{L}$ of 2 mM PCR_BMP2_rv 
and $1 \mu \mathrm{L}$ Taq pol). The PCR reaction was performed to a standard PCR protocol. Positive PCR reaction was extracted, and their plasmids DNA were sequenced at Macrogen company.

\section{rhBMP-2 production and purification}

The pTZ/BMP-2 was digested with NcoI and BamHI restriction enzymes, and the fragment that contains the hBMP-2 CDS was cloned into the expression vector pET-28a (rhBMP-2) that carries a gene encoding kanamycin resistance. The expression vector construct pET-28a/hBMP-2 was transformed into E. coli BL21 (DE3) (Stratagene) cells. For purification, cells from $5 \mathrm{~L}$ cultures were lysed by sonication at 300 watts for $5 \mathrm{~min}$ on ice (Sonics Vibra cell $750^{\mathrm{TM}}$ with Ti tip of $1 / 2$ inch), and inclusion bodies were extracted and purified. Refolding of rhBMP2 was performed according to published protocols by Ruppert and colleagues in 1996 (Ruppert et al., 1996), except that SP-sepharose column was used for purification. The expression level of rhBMP2 in E. coli was analyzed by SDS-PAGE using a mini-protean electrophoresis system $\left(\right.$ Biorad $\left.^{\circledR}\right)$. The protein folding and the purification of rhBMP-2 homodimer were also checked by SDS-PAGE. The rhBMP-2 bands were visualized by staining with Coomassie blue R-250. The fractions were pooled and concentrated with Amicon system ${ }^{\circledR}$ to $1 \mathrm{mg} / \mathrm{mL}$. Afterwards, rhBMP-2 was lyophilized and stored at $-40^{\circ} \mathrm{C}$ until it was used.

\section{Biological activity of rhBMP-2}

Murine $\mathrm{C} 2 \mathrm{C} 12$ skeletal myoblasts ( $<30$ passages, obtained from the American Type Culture Collection, ATCC) were maintained in growth medium: Dulbecco's Modified Eagle Medium (DMEM) (SigmaAldrich) supplemented with $10 \%$ fetal bovine serum (FBS) (Invitrogen) and 1\% antibiotic-antimycotic (Invitrogen) in a $37^{\circ} \mathrm{C}, 5 \% \mathrm{CO}_{2}$ incubator. Osteoblast differentiation was induced by seeding $\mathrm{C} 2 \mathrm{C} 12$ cells at a density of $50000 \mathrm{cell} / \mathrm{mL}$ in growth medium with different concentrations of rhBMP-2 and $300 \mathrm{ng} / \mathrm{mL}$ of commercial rhBMP-2 in a 48 wellplate at $37^{\circ} \mathrm{C}$ in a $5 \% \mathrm{CO}_{2}$ incubator $^{\mathrm{TM}}$ (Thermo Fisher Scientific). After 3 days the cells were washed twice with PBS and lysed in $50 \mathrm{mM}$ Tris $\mathrm{pH} 6.8$, $0.1 \%$ Triton $\mathrm{X}-100,2 \mathrm{mM} \mathrm{MgCl}_{2}$ buffer. The ALP activity of the lysates was assayed at $37^{\circ} \mathrm{C}$ in 100 $\mu \mathrm{L}$ of 2-amino-2-methyl-l-propanol buffer, $\mathrm{pH} 10.3$, for $15 \mathrm{~min}$ using p-nitrophenylphosphate (pNPP) (Merck) as a substrate. The reaction was stopped with $100 \mu \mathrm{L}$ of $0.5 \mathrm{M} \mathrm{NaOH}$ and the absorbance was measured at $405 \mathrm{~nm}$ on a Varioskan ${ }^{\mathrm{TM}}$ LUX multimode microplate reader (Thermo Fisher Scientific). The enzyme activity was expressed as micromoles of p-nitrophenol ( $\mathrm{pNP}$ ) produced per min per $\mu \mathrm{g}$ of protein. The protein content was determined using the BCA protein assay kit (Sigma-Aldrich) using BSA as the standard.

\section{Cell mineralization}

To test whether the differentiated $\mathrm{C} 2 \mathrm{C} 12$ cells could synthesize calcium nodules; completing their differentiation into functional osteoblasts, $\mathrm{C} 2 \mathrm{C} 12$ cells were cultured with $3000 \mathrm{ng} / \mathrm{mL}$ of rhBMP-2 in mineralization media: DMEM, 10\% FBS and 1\% antibiotic-antimycotic, $1 \mathrm{mM}$ of $\beta$-sodium Glycerophosphate (Sigma-Aldrich), $50 \mu \mathrm{g} / \mathrm{mL}$ of ascorbic acid (Sigma-Aldrich) and $10^{-8} \mathrm{M}$ of Dexamethasone (Sigma-Aldrich). After 21 days in culture, cells were washed twice with PBS without $\mathrm{Ca}^{+}$and $\mathrm{Mg}^{+}$, fixed with ethanol for $15 \mathrm{~min}$ and stained with $40 \mathrm{mM}$ of alizarin red for $15 \mathrm{~min}$ to detect mineralization zones using a Nikon Eclipse TS100$\mathrm{F}$ inverted microscope (NIKON). Osteoblastic cells Saos-2 $(<30$ passages, obtained from the American Type Culture Collection, ATCC) in mineralization media were used as a positive mineralization control. Mineralization percentage was calculated using ImageJ.

\section{3-D model construction of BMP-2}

Protein was visualized with Molecular Graphics Tool (PyMOL) (DeLano, 2002), and using the PDB file 3BMP.

\section{Statistical analysis}

ANOVA and Tukey's Multiple Comparison Test were used to determine statistical differences between cells treated with different concentrations of BMP-2 at 0.05 level of significance by using GraphPad PrismVersion 5 software. 


\section{RESULTS}

\section{BMP-2 synthetic gene construction and DNA se- quencing}

The experiment to produce the synthetic CDS of the BMP-2 mature peptide was successfully performed as described in the methods section. The long oligonucleotides were successfully elongated and finally merged into a DNA molecule of $335 \mathrm{bp}$ (figure $1)$. The PCR product was ligated into the NcoI / BamHI sites of the expression vector pET28a. The

\section{UniProt BMP-2 P12643}

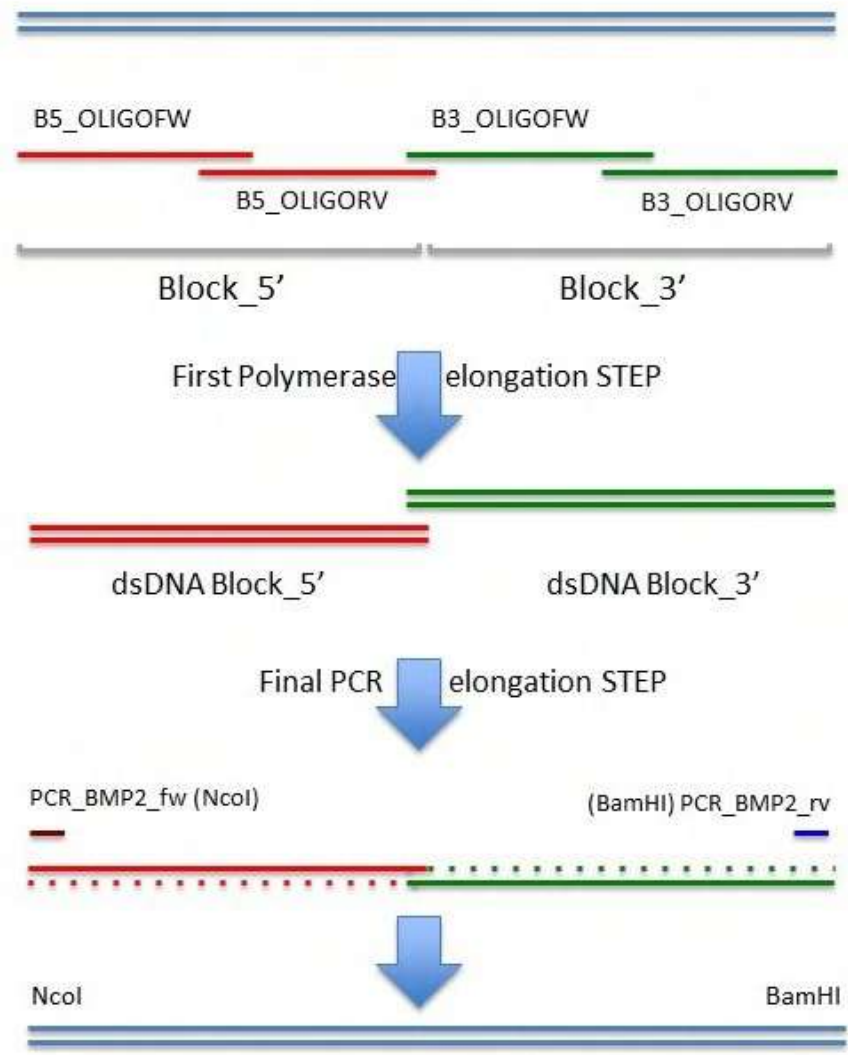

Synthetic BMP-2 CDS 283-396

Figure 1. Schematic representation of the construct used to express the human BMP-2 CDS. Oligos were synthesized according to the sequence reported on PDB Database. Last amplification with end primers $\mathrm{Ncol}$ and BamHI generates a CDS of rhBMP-2 gene.

insert sequence was confirmed by Macrogen service using capillary sequencing with the primers T7promoter and T7terminator (data not shown).

\section{rhBMP-2 purification}

The rhBMP-2 was expressed as an insoluble form in the IB of E. coli BL21. To recover the protein, the IB were sonicated using a cell disrupter (Sonics, VibraCell ${ }^{\mathrm{TM}} 750$ ) at an amplitude of $40 \%$ and power of 300 watts. After purification, the concentration of IB was $20 \%$ of the wet weight of bacteria paste. The IB were solubilized as described by Ruppert et al. (1996), but instead of using 2-mercaptoethanol we used $5 \mathrm{mM}$ DTT to obtain the protein. The protein was refolded using a redox system composed of oxidized and reduced glutathione. This process resulted in a BMP-2 concentration of $1 \mathrm{mg} / \mathrm{ml}$. Afterwards, about $30 \%$ of the total protein was visualized as a monomer and approximately $70 \%$ formed a dimer (figure 2).
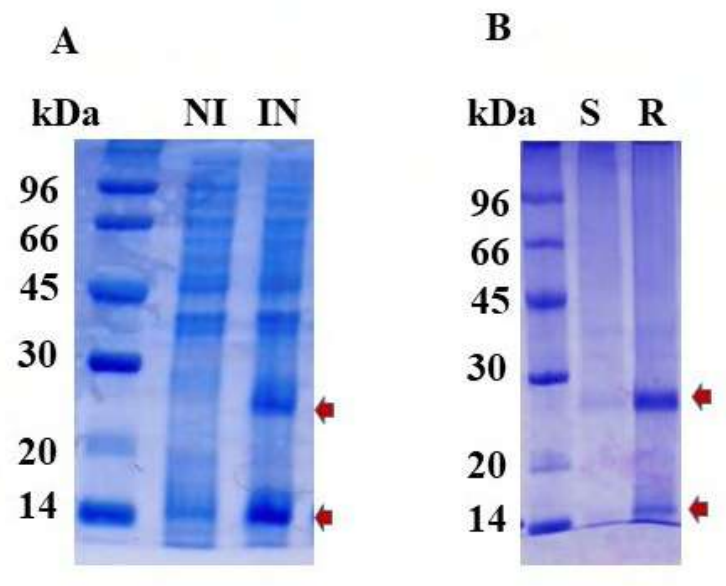

Figure 2. Analysis of the rhBMP-2 expression. (A) Induction of rhBMP-2 protein with IPTG. (B) Refolding of rhBMP-2 and purification by SP-sepharose. Protein was analyzed by $12 \%$ SDS-PAGE and stained by Coomassie Brilliant Blue. (kDa) molecular low marker, (NI) no induction, (IN) IPTG induction, (S) flow through from Amicon system, (R) concentrated hBMP-2 fractions by Amicon system after SPsepharose purification. The red arrows show the rhBMP-2 dimer (26 kDa) and monomers (13 kDa). 
SP-sepharose column was employed to separate the BMP-2 monomer from the BMP-2 dimer. Proteinbound to the column was eluted from the SPsepharose column with a $\mathrm{NaCl}$ gradient from 200 $\mathrm{mM}$ to $1 \mathrm{M}$ (figure 2 ). We observed that this solution contained possibly $80 \%$ of dimeric BMP-2. It means that after purification, the presence of monomers was highly reduced. After elution, BMP-2 was lyophilized and stored at $-40^{\circ} \mathrm{C}$. After the $2 \mathrm{~L}$ culture, $200 \mathrm{mg}$ of wet IB, the protein recovery was $500 \mu \mathrm{g}$.

\section{Biological activity of rhBMP-2}

The refolded human BMP-2 bioactivity was tested by measuring ALP production in mouse myoblastic cell line $\mathrm{C} 2 \mathrm{C} 12$. After 3 days in culture, there were statistical differences between cells cultured with $3000 \mathrm{ng} / \mathrm{mL}$ of our rhBMP-2 and without rhBMP-2 (controls), increasing ALP activity by approximately 137\%. Additionally, we found significant differences between cells cultured with $300 \mathrm{ng} / \mathrm{mL}$ of commercial rhBMP-2 and controls. However, there were no statistical differences between cells cultured with our rhBMP-2 (3000 ng/mL) and commercial (300 $\mathrm{ng} / \mathrm{mL}$ ) rhBMP-2. According to these results, we were satisfied to prove that the rhBMP-2 derived from our synthetic CDS could induce the differentiation of $\mathrm{C} 2 \mathrm{C} 12$ cells towards an osteogenic lineage (figure 3 and table 1).

After 21 days in mineralization media, Alizarin red staining showed that both Saos-2 (osteoblastic osteosarcoma) and $\mathrm{C} 2 \mathrm{C} 12$ cells induced with rhBMP-2 could synthesize calcium nodules (figure 4) mineralizing the surface $84 \%$ and $73 \%$, respectively. This demonstrates that our rhBMP-2 can differentiate $\mathrm{C} 2 \mathrm{C} 12$ cells into functional osteoblasts.

\section{DISCUSSION}

BMPs play a central role in bone formation and fracture healing. The FDA (Food and Drug Administration, USA) has commercially approved two recombinant BMPs for clinical applications, among them rhBMP-2 (Durham et al., 2018; Krishnakumar et al., 2017). Our goal was to find a suitable protocol for cloning, expressing, and purifying rhBMP-2; which could serve as a basis for large-scale production

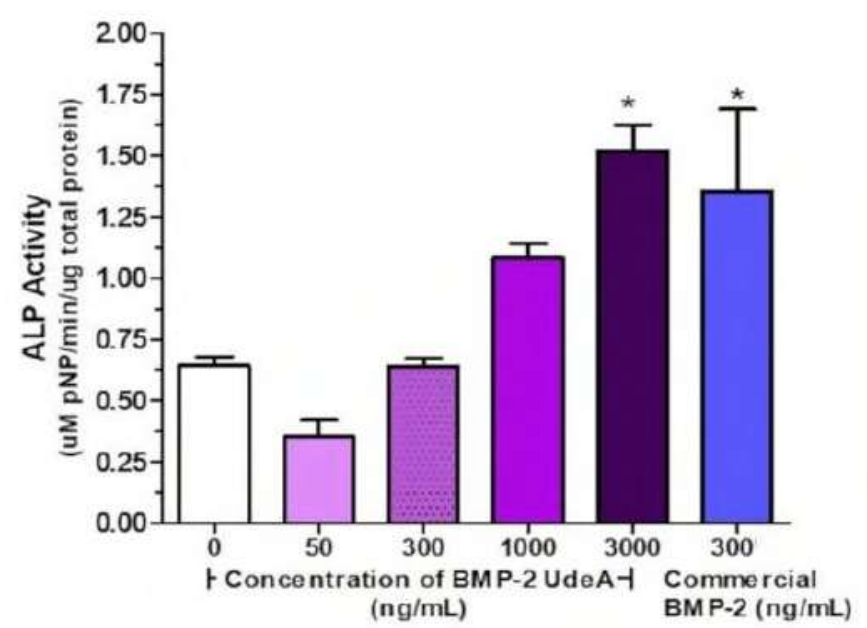

Figure 3. rhBMP-2 bioactivity. Refolded and SPsepharose purified rhBMP-2 bioactivity was tested by ALP production, which hydrolysis $p$-NPP into pNP, per total protein content in C2C12 cells cultured for 3 days with different concentrations of rhBMP-2 (in house) and $300 \mathrm{ng} / \mathrm{mL}$ of commercial rhBMP-2. A representative experiment of three independent experiments. Mean + Standard error. Anova and Tukey's Multiple Comparison Test. * indicates statistical differences between concentrations of BMP-2 and 0, 50 or $300 \mathrm{ng} / \mathrm{mL}$.

processes. PCR-based synthesis of the human BMP2 CDS, corresponding to the 283-396 amino acids of the mature region of the protein, proved here to be a low-cost, reliable and fast strategy (Park et al., 2019). The rhBMP-2 protein was efficiently expressed in E. coli under the control of the T7 promoter. The dimerization of the protein was achieved using the same refolding and the purification conditions employed by Ruppert et al. (1996), except that we used an SP-sepharose column, instead of a CM-sepharose column to obtain the rhBMP-2. Our results are in agreement with previous data, which reported efficient rhBMP-2 production in bacteria (Sharapova et al., 2010; Von Einem et al., 2010). The accumulation of rhBMP-2 in IB made necessary a refolding procedure, which is time-consuming, complicated and low-yield. However, the interactions between all atoms in the amino acids sequence of BMP-2 and the buffer conditions supplemented with a redox system allowed the majority of BMP-2 monomers to reach the native structure of the pro- 
Table 1. Bioactivity of different concentrations of hBMP-2 and $300 \mathrm{ng} / \mathrm{mL}$ of commercial BMP-2

\begin{tabular}{l|l|l|l|l|l}
\hline $\begin{array}{l}\text { Tukey's Multiple } \\
\text { Comparison Test }\end{array}$ & $\begin{array}{l}\text { Mean } \\
\text { Difference }\end{array}$ & q value & $\begin{array}{l}\text { Significant? } \\
\mathbf{p}<0.05 ?\end{array}$ & Summary & 95\% Cl of difference \\
\hline 0 vs 50 & 0.290300 & 1.94900 & No & Ns & -0.4172 to 0.9978 \\
0 vs 300 & 0.002748 & 0.01845 & No & Ns & -0.7048 to 0.7103 \\
0 vs 1000 & -0.439100 & 2.94800 & No & Ns & -1.147 to 0.2684 \\
0 vs 3000 & -0.876400 & 5.88500 & Yes & $*$ & -1.584 to -0.1689 \\
0 vs $300^{\circ}$ & -0.711600 & 4.77800 & Yes & $*$ & -1.419 to -0.004075 \\
50 vs 300 & -0.287600 & 1.93100 & No & Ns & -0.9951 to 0.4200 \\
50 vs 1000 & -0.729400 & 4.89800 & Yes & $*$ & -1.437 to -0.02186 \\
50 vs 3000 & -1.167000 & 7.83500 & Yes & $* *$ & -1.874 to -0.4592 \\
50 vs $300^{\circ}$ & -1.002000 & 6.72800 & Yes & $* *$ & -1.709 to -0.2944 \\
300 vs 1000 & -0.441800 & 2.96700 & No & Ns & -1.149 to 0.2657 \\
300 vs 3000 & -0.879200 & 5.90400 & Yes & $*$ & -1.587 to -0.1717 \\
300 vs $300^{\circ}$ & -0.714300 & 4.79700 & Yes & $*$ & -1.422 to -0.006823 \\
1000 vs 3000 & -0.437400 & 2.93700 & No & Ns & -1.145 to 0.2702 \\
1000 vs $300^{\circ}$ & -0.272500 & 1.83000 & No & Ns & -0.9800 to 0.4350 \\
3000 vs $300^{\circ}$ & 0.164900 & 1.10700 & No & Ns & -0.5427 to 0.8724 \\
\hline
\end{tabular}

CI: confidence interval, Ns: not significant

$*$ p value $<0.05, * *$ p value $<0.01$

tein and its corresponding free energy minimum (figure 5) (Basak et al., 2019; Englander and Mayne, 2014). As a result, we obtained an active rhBMP2 with $70 \%$ or more of purity. The rhBMP-2 could induce osteoblast differentiation of $\mathrm{C} 2 \mathrm{C} 12$ cells at $3000 \mathrm{ng} / \mathrm{mL}$ (figure 3 and table 1). Although we needed higher doses of synthetic BMP-2 to induce the osteogenic differentiation of $\mathrm{C} 2 \mathrm{C} 12$ cells, they are in line with reported doses in other studies (Fung et al., 2019; Ihm et al., 2008; Kashiwagi et al., 2009). When we compared the ALP activity of the commercial rhBMP-2 and ours at $300 \mathrm{ng} / \mathrm{mL}$, we found that our BMP-2, unlike the commercial one, was not statistically different from the control. While at $3000 \mathrm{ng} / \mathrm{mL}$ we did not find statistical differences between the two. It is possible that impurities left after protein dimerization and purification using SPsepharose cation exchanger column might be interfering with our protein, reducing its activity (figure 3 ). Other studies use heparin chromatography to purify BMP-2 (Hettiaratchi et al., 2020; Xiong et al., 2008). In heparin chromatography purification, heparin acts as an affinity ligand for both the monomer and dimer of BMP-2. It also acts as an ion exchanger column that under increasing $\mathrm{NaCl}$ concentrations elutes either the monomer or the dimmer (Xiong et al., 2008). This dual action of the heparin column increases specificity of the process, obtaining a purer
BMP-2. Considering this, in the future, we will use a heparin column and optimize the purification process to obtain the rhBMP-2 with a greater purity that needs lower doses to induce the osteogenic differentiation of $\mathrm{C} 2 \mathrm{C} 12$ cells.

Despite these issues, the resulting rhBMP-2 is clearly functional and induces ALP activity in $\mathrm{C} 2 \mathrm{C} 12$ cells, which can further differentiate into functional mineralizing osteoblasts. This means that the dimer of rhBMP-2 protein was folded correctly and can bind to its specific receptors, receptors type I (BMPR-Ia) and type II (ActRII) (Mueller \& Nickel, 2012; Nickel \& Mueller, 2019; Tabisz et al., 2017). Nevertheless, in the future, we will continue optimizing the protein purification procedure to obtain a purer BMP-2.

This work opens the possibility of scaling up the BMP-2 production to facilitate the study of bone tissue regeneration strategies. It also opens the possibility of expanding our biotechnology industry by synthesizing a functional protein which could be used to generate polyclonal antibodies for western blot applications, enzyme-linked immunosorbent assays, etc. 

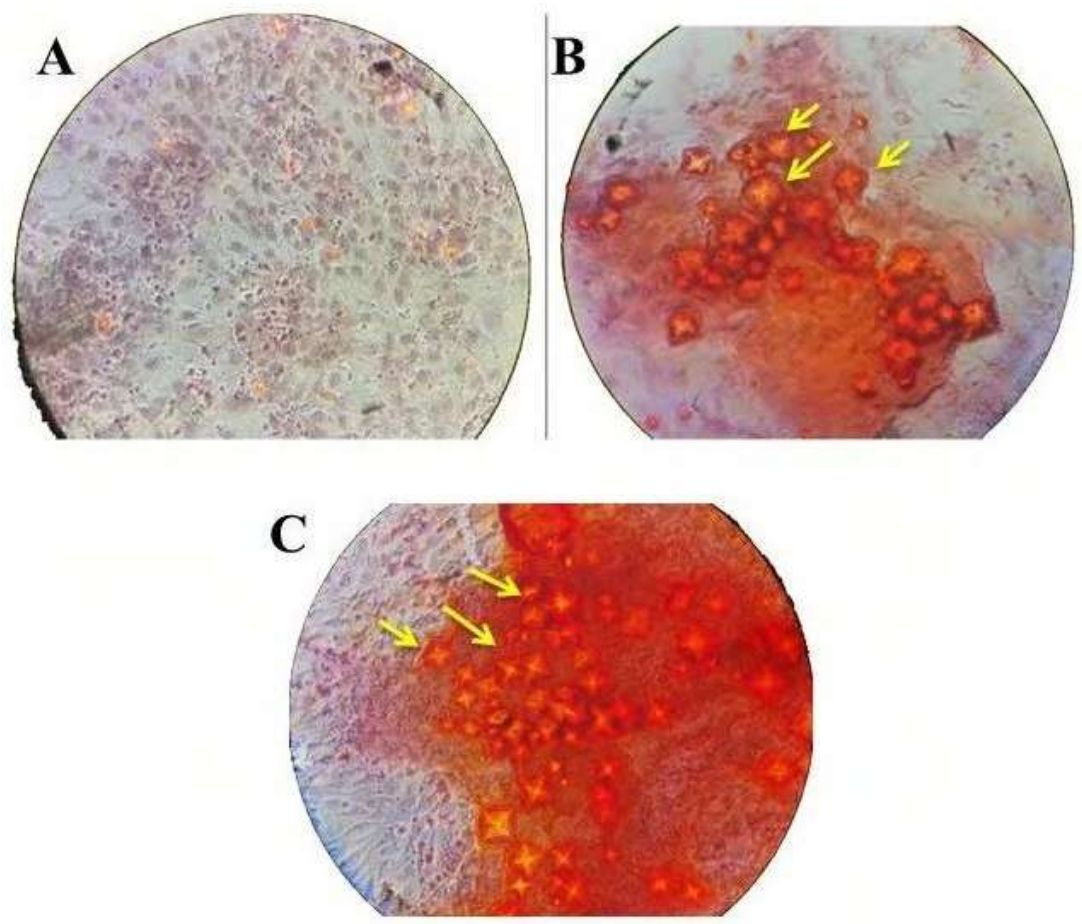

Figure 4. Effect of increased intracellular calcium nodules by rhBMP-2 treatment for 21 days on C2C12 and Saos- 2 cells. Mineralized nodules formed by differentiated cells after incubation with rhBMP-2 were stained with Alizarin red (yellow arrows). (A and B) C2C12 cells in mineralization media with and without $3000 \mathrm{ng} / \mathrm{mL}$ of hBMP-2, respectively. (C) Saos-2 cells in mineralization media (positive control). $40 \mathrm{X}$ magnification.

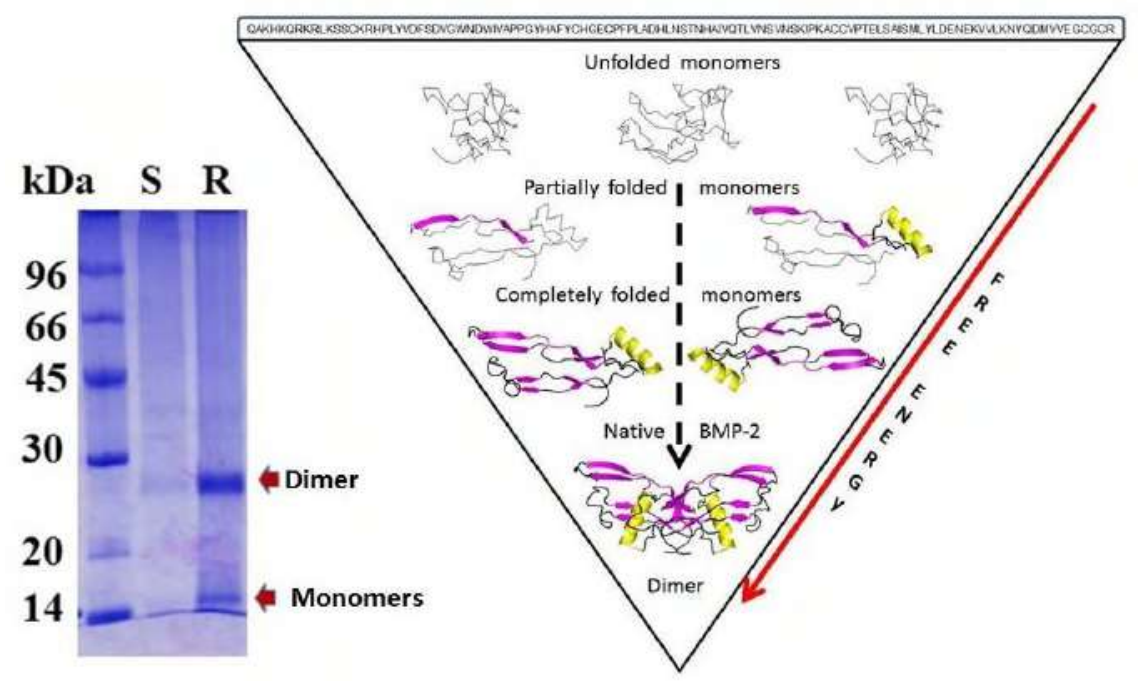

Figure 5. BMP-2 dimer. The SDS-PAGE for the monomers and dimer BMP-2 after chromatography purification (left side). A brief schematic for BMP-2 folding is shown (right side). All monomers started in the denatured state (amino acid sequence) (upper). After that, some monomers present secondary structures such as $\alpha$ helix or $\beta$-sheets (medium). Finally, correctly folded monomers bound to form the BMP-2 dimer (bottom). These structures were visualized with PyMOL. The red arrow indicates a decrease in the free energy of monomers to reach the native state. 


\section{ACKNOWLEDGMENTS}

This work was supported by Colciencias, Grant \#COL-13-2-16. Andrea Mesa Restrepo would like to thank the University of Antioquia for funding her and Juan José Pavón, and Junes Villarraga for providing scientific guidance. Thanks go to Victoria Ospina for providing the mineralization media and Saos-2 cells. Finally, the authors would like to thank Professor Norman Balcázar for proving not only scientific guidance but also providing the $\mathrm{C} 2 \mathrm{C} 12$ cells and allowing us to use his equipment and reagents. Thanks to AM LTDA and Transferencia Tecnológica from UdeA for funding the project CODI-UdeA grant \#2017-18192 for supporting the BMP-2 production.

\section{CONFLICT OF INTEREST}

The authors have no conflicts of interest to declare.

\section{REFERENCES}

Allendorph, G.P., Vale, W.W., \& Choe, S. (2006). Structure of the ternary signaling complex of a TGF- $\beta$ superfamily member. Proceedings of the National Academy of Sciences of the United States of America, 103(20), 7643-7648. DOI:10.1073/pnas.0602558103

Bahney, C.S., Zondervan, R.L., Allison, P., Theologis, A., Ashley, J.W., Ahn, J., Miclau, T., Marcucio, R.S., \& Hankenson, K.D. (2019). Cellular biology of fracture healing. Journal of Orthopaedic Research, 37(1), 35-50. DOI:10.1002/jor.24170

Basak, S., Paul Nobrega, R., Tavella, D., Deveau, L. M., Koga, N., Tatsumi-Koga, R., Baker, D., Massi, F., \& Robert Matthews, C. (2019). Networks of electrostatic and hydrophobic interactions modulate the complex folding free energy surface of a designed $\beta \alpha$ protein. Proceedings of the National Academy of Sciences of the United States of America, 116(14), 6806-6811. DOI:10.1073/pnas.1818744116

DeLano, W.L. (2002). PyMOL: An open-source molecular graphics tool. CCP4 Newsletter On Protein Crystallography, 40, 82-92. http://148.79.162.84/newsletters/ newsletter40/11_pymol.pdf

Durham, E.L., Howie, R.N., Hall, S., Larson, N., Oakes, B., Houck, R., Grey, Z., Steed, M., Larue, A.C., MuiseHelmericks, R., \& Cray, J. (2018). Optimizing bone wound healing using BMP2 with absorbable collagen sponge and Talymed nanofiber scaffold 11 Medical and Health Sciences 1103 Clinical Sciences 09 Engineering 0903 Biomedical Engineering. Journal of Translational Medicine, 16(1), 1-8. DOI:10.1186/s12967-018-1697-y
Englander, S.W., \& Mayne, L. (2014). The nature of protein folding pathways. Proceedings of the National Academy of Sciences of the United States of America, 111 (45), 1587315880. DOI:10.1073/pnas.1411798111

Fung, S.L., Wu, X., Maceren, J.P., Mao, Y., \& Kohn, J. (2019). In vitro evaluation of recombinant bone morphogenetic protein-2 bioactivity for regenerative medicine. Tissue Engineering - Part C: Methods, 25(9), 553-559. DOI:10.1089/ten.tec.2019.0156

Hettiaratchi, M.H., Krishnan, L., Rouse, T., Chou, C., McDevitt, T.C., \& Guldberg, R.E. (2020). Heparin-mediated delivery of bone morphogenetic protein-2 improves spatial localization of bone regeneration. Science Advances, 6(1), 1-12. DOI:10.1126/sciadv.aay1240

Ihm, H.J., Yang, S.-J., Huh, J.-W., Choi, S.Y., \& Cho, S.-W. (2008). Soluble expression and purification of synthetic human bone morphogenetic protein-2 in Escherichia coli. BMB Reports, 41(5), 404-407. DOI:10.5483/BMBRep.2008.41.5.404

Kashiwagi, K., Tsuji, T., \& Shiba, K. (2009). Directional BMP-2 for functionalization of titanium surfaces. Biomaterials, 30(6), 1166-1175. DOI:10.1016/j.biomaterials.2008.10.040

Kim, H.S., Neugebauer, J., McKnite, A., Tilak, A., \& Christian, J.L. (2019). BMP7 functions predominantly as a heterodimer with BMP2 or BMP4 during mammalian embryogenesis. ELife, 8, 1-22. DOI:10.7554/eLife.48872

Krauss, I.R., Merlino, A., Vergara, A., \& Sica, F. (2013). An overview of biological macromolecule crystallization. International Journal of Molecular Sciences, 14(6), 1164311691. DOI:10.3390/ijms140611643

Krishnakumar, G.S., Roffi, A., Reale, D., Kon, E., \& Filardo, G. (2017). Clinical application of bone morphogenetic proteins for bone healing: a systematic review. International Orthopedics, 41, 1073-1083. DOI:10.1007/s00264017-3471-9

Long, S., Truong, L., Bennett, K., Phillips, A., Wong-Staal, F., \& Ma, H. (2006). Expression, purification, and renaturation of bone morphogenetic protein-2 from Escherichia coli. Protein Expression and Purification, 46(2), 374-378. DOI:10.1016/j.pep.2005.09.025

Mevel, R., Draper, J.E., Lie-A-Ling, M., Kouskoff, V., \& Lacaud, G. (2019). RUNX transcription factors: Orchestrators of development. Development (Cambridge), 146, 119. DOI:10.1242/dev. 148296

Miyazono, K., Kamiya, Y., \& Morikawa, M. (2010). Bone morphogenetic protein receptors and signal transduction. Journal of Biochemistry, 147(1), 35-51. DOI:10.1093/jb/mvp148

Mueller, T.D., \& Nickel, J. (2012). Promiscuity and specificity in BMP receptor activation. FEBS Letters, 586(14), 1846-1859. DOI:10.1016/j.febslet.2012.02.043

Nickel, J., \& Mueller, T.D. (2019). Specification of BMP Signaling. Cells, 8(12), 1579. DOI:10.3390/cells8121579

Park, S.Y., Kim, K.H., Kim, S., Lee, Y.M., \& Seol, Y.J. (2019). BMP-2 gene delivery-based bone regeneration in dentistry. Pharmaceutics, 11(8), 1-23. DOI:10.3390/pharmaceutics11080393

Rahman, M.S., Akhtar, N., Jamil, H.M., Banik, R.S., \& Asaduzzaman, S.M. (2015). TGF- $\beta$ /BMP signaling and 
other molecular events: Regulation of osteoblastogenesis and bone formation. Bone Research, 3, Article 15005. DOI:10.1038/boneres.2015.5

Ruehle, M.A., Krishnan, L., Vantucci, C.E., Wang, Y., Stevens, H.Y., Roy, K., Guldberg, R.E., \& Willett, N.J. (2019). Effects of BMP-2 dose and delivery of microvascular fragments on healing of bone defects with concomitant volumetric muscle loss. Journal of Orthopaedic Research, 37(3), 553-561. DOI:10.1002/jor.24225

Ruppert, R., Hoffmann, E., \& Sebald, W. (1996). Human bone morphogenetic protein 2 contains a heparin-binding site which modifies its biological activity. European Journal of Biochemistry, 237(1), 295-302. DOI:10.1111/j.14321033.1996.0295n.x

Saraff, V., Narayanan, V.K., Lawson, A.J., Shaw, N.J., Preece, M.A., \& Högler, W. (2016). A diagnostic algorithm for children with low alkaline phosphatase activities: Lessons learned from laboratory screening for hypophosphatasia. Journal of Pediatrics, 172, 181-186e1. DOI:10.1016/j.jpeds.2016.01.045

Scheufler, C., Sebald, W., Hulsmeyer, M., Hu, M., \& Hülsmeyer, M. (1999). Crystal Structure of $\mathrm{Hu}-$ man Bone Morphogenetic Protein-2 at 2.7 A Resolution. Journal of Molecular Biology, 287, 103-115. DOI:10.1006/jmbi.1999.2590

Sharapova, N.E., Kotnova, A.P., Galushkina, Z.M., Lavrova, N.V., Poletaeva, N.N., Tukhvatulin, A.E., Semikhin, A.S., Gromov, A.V., Soboleva, L.A., Ershova, A.S., Zaitsev, V.V., Sergienko, O.V., Lunin, V.G., \& Karyagina, A.S. (2010). Production of the recombinant human bone morphogenetic protein-2 in Escherichia coli and testing of its biological activity in vitro and in vivo. Molecular Biology, 44(6), 923-930. DOI:10.1134/S0026893310060099

Tabisz, B., Schmitz, W., Schmitz, M., Luehmann, T., Heusler, E., Rybak, J., Meinel, L., Fiebig, J.E., Mueller, T.D., \& Nickel, J. (2017). Site-Directed Immobilization of BMP2: Two Approaches for the Production of Innovative Osteoinductive Scaffolds. Biomacromolecules, 18(3):695708. DOI:10.1021/acs.biomac.6b01407

Uday, S., Matsumura, T., Saraff, V., Saito, S., Orimo, H., \& Högler, W. (2019). Tissue non-specific alkaline phosphatase activity and mineralization capacity of biallelic mutations from severe perinatal and asymptomatic hypophosphatasia phenotypes: Results from an in vitro mutagenesis model. Bone, 127(January), 9-16. DOI:10.1016/j.bone.2019.05.031

Vallejo, L.F., Brokelmann, M., Marten, S., Trappe, S., CabreraCrespo, J., Andrea Hoffmann, A., Gross, G., Weich, H.A., \& Rinas, U. (2002). Renaturation and purification of bone morphogenetic protein- 2 produced as inclusion bodies in high-cell-density cultures of recombinant Escherichia coli. Journal of Biotechnology, 94(2), 185-194. DOI:10.1016/S0168-1656(01)00425-4

Von Einem, S., Schwarz, E., \& Rudolph, R. (2010). A novel TWO-STEP renaturation procedure for efficient production of recombinant BMP-2. Protein Expression and Purification, 73(1), 65-69. DOI:10.1016/j.pep.2010.03.009

Xiong, S., Zhang, L., \& He, Q.-Y. (2008). Fractionation of proteins by heparin chromatography. Methods in Molecular Biology (Clifton, N.J.), 424, 213-221. DOI:10.1007/978-
1-60327-064-9 18

Yilgor, P., Tuzlakoglu, K., Reis, R. L., Hasirci, N., \& Hasirci, V. (2009). Incorporation of a sequential BMP2/BMP-7 delivery system into chitosan-based scaffolds for bone tissue engineering. Biomaterials, 30(21), 35513559. DOI:10.1016/j.biomaterials.2009.03.024 